\title{
ETNOBOTANY MEDICINAL PLANTS TREE GROUP IN TRADITIONAL MEDICINE AT EAST LOMBOK REGENCY
}

\author{
Lalu Gin Gin Budiarsa, Nurrachman, Sumarjan \\ Mataram University, West Nusa Tenggara-Indonesia \\ Faculty of Agriculture, Mataram University, West Nusa Tenggara - Indonesia \\ Email: lalu.egin11@gmail.com,nurrachman.deden@unram.ac.id, \\ sumarjan@unram.ac.id
}

\begin{abstract}
Traditional medicine (Batra) plays a strategic role in society. In addition to working as an alternative treatment, traditional medicine provides an overview of local wisdom found in a community group. This study aims to determine the diversity of species and ethnobotany of medicinal tree group plants by traditional healers in East Lombok Regency. The research method uses descriptive qualitative method. The sampling technique of the respondents was using Puspossive Randome Sampling, while the sampling of plants was using Stratified Sampling. The results of the study include two groups, namely the companion variable consisting of the characteristics of the research area and the characteristics of the research respondents. The characteristics of the area function to determine the development of plants found in agricultural cultivation activities, while the characteristics of the respondents correlate with the species of medicinal trees used. Then in the main variables found 36 species of medicinal plants used by Batra. The tree group plants which were subsequently found mapped the optimal cultivation location in the research area by examining their use to determine the potential for plant development as a commodity in agricultural cultivation.
\end{abstract}

Keywords: Traditional Medicine (Batra); Tree Group; Ethnobotany

Received: 2021-11-22; Accepted: 2021-12-05; Published: 2021-12-20

\section{Introduction}

Communities on the island of Lombok have empirically utilized various types of plants as a medicinal ingredient to treat a symptom of a disease. According to (Dewi, Jamhari, \& Isnainar, 2017), Utilization of medicinal plants starts from trial activities by ancestors until become a knowledge that is passed down from generation to generation, then from the test results try to get medicinal herbs known as herbs and medicinal plants family (Toga) (Dahlia, 2016).

Treatment using plant ingredients with medicinal properties is mostly rely on the experience gained by Batra, without referring to or making written guide. This causes quite a bit of stored information (Abdullah, Mustikaningtyas, \& Widiatningrum, 2010). Little information and scientific evidence regarding the use of medicinal plants result in

$\begin{array}{ll}\text { How to cite: } & \text { Budiarsa, L, G, G., Nurrachman, \& Sumarjan (2021) Etnobotany Medicinal Plants Tree Group In } \\ & \text { Traditional Medicine At East Lombok Regency, Syntax Idea, 3(12), https://doi.org/10.36418/syntax- } \\ & \text { idea.v3i12.1668 } \\ \text { E-ISSN: } & \text { 2684-883X } \\ \text { Published by: } & \text { Ridwan Institute }\end{array}$


an element of trial and error in treating a disease complaint, so that the occurrence of side effects of resistance, a symptom of a disease resulting from the use of medicinal plants that are not appropriate (Suryanto \& Setiawan, 2013).

Strategically efficacious medicinal plants have the potential to be developed as one of the community's home industry by considering the content of active compounds in medicinal plants. Medicinal plants used for traditional medicine must be its existence is preserved through cultivation activities, so that its existence remains in the optimal conditions (Gazali, M., Zamani, N., Nurjanah, 2011).

Preservation of medicinal plants through cultivation activities can prevent scarcity medicinal plants, as well as reducing the risk of loss of medicinal plant ingredients due to scarcity medicinal plants used (Lesmana, Alfianur, Utami, Retnowati, \& Darni, 2018). Before doing activities cultivation, information on commodities and types of plants is needed, as well as the frequency of its use in traditional medicine (Batra), so that it can be seen the potential of these medicinal plants to be developed. Therefore, it is necessary to carry out activities exploration that aims to determine the conditions and assess the potential of group plants trees as medicinal ingredients by Batra (Herdiani, 2012).

Medicinal plant commodities whose use is known in the community through exploration activities, then intensively cultivated to increase production. The purpose of plant cultivation activities in addition to increasing production, also serves to optimize the content of active ingredients in plants. It is important because, currently most of the medicinal plants used in traditional medicine only rely on direct production in nature, so it is often difficult to find and the quality of the active ingredients of medicinal plants is less than optimal (Nugroho, 2017).

Group of medicinal plants that have a high frequency of use by Batra in Pulau Lombok one of which is a medicinal plant group of trees. Many tree groups used because it is easier to obtain and is believed to have high efficacy optimal for treatment. Various medicinal plant commodities of the tree group have been used by the community, some commodities are widely used such as seeds, nutmeg (Myristica fragrance), tamarind pulp (Tamarindus fructus) and seed endosperm areca nut (Areca catechu) (Ariandi \& Khaerati, 2016).

Communities on the island of Lombok are familiar with the use of tree groups hereditary as a medicinal ingredient. One of the areas on the island of Lombok where the people has long used various types of plants as medicinal ingredients, namely East Lombok. Treatments carried out in East Lombok in addition to using various types of medicinal plants combined with various therapies or trusted readings can increase the effectiveness of the medicinal plants used (Riswan \& Andayaningsih, 2008).

Traditional medicine using various types of plants medicine has a strategic position in society as an alternative treatment, so that has the potential to be developed both the plants used and the treatment done (Riau, 2019).

The purpose of this research is to know the potential of the tree group medicinal properties include diversity of plant species, frequency of use, location of growth, and 
how to use it by traditional healers in East Lombok Regency, as the first step in inventory activities to be developed in cultivation agriculture.

\section{Methods}

The research method uses descriptive qualitative methods. Research was conducted from July to August 2021. Location of research is in East Lombok Regency, West Nusa Tenggara Province. The main instrument of the study used a questionnaire as a research guide. The sampling method of respondents used snowball random sampling. This method was chosen because data regarding the number and location of Batra in East Lombok Regency were not yet available in related references or institutions, so respondents mapped themselves on research activities. Then the plant sampling method uses Stratified Sampling based on a predetermined category, namely the optimal growth category, so that the optimal growth location for the tree plant groups that have been found can be mapped.

Data collection techniques through two stages. The first stage is to collect information on medicinal plant species used in Batra which have been mapped to become research respondents. The techniques used are observation, documentation and questionnaires accompanied by interviews with Batra. The primary data obtained regarding plant species as well as the frequency of use and how to use them were obtained in the form of the local language, so that re-testing with related reference sources regarding the plant species used to obtain data on the validity of the plant species used (Nasution, Erlina, \& Muda, 2020). The second stage is plant vegetation analysis to determine the availability of plant populations in the study area. Each plant species obtained from the results of research on Batra mapped its optimal growth location in agricultural cultivation activities in East Lombok Regency. Location mapping based on the number of plant populations and optimal growing conditions in the division of climate zones in East Lombok Regency based on the Oldeman climate type.

The research variables consisted of two groups, namely the companion variable and the main variable. The companion variables consist of regional characteristics obtained from the synthesis of secondary data from the statistical center of East Lombok Regency in the last five years to determine the climate zone of each sub-district contained in the research area and the characteristics of respondents including gender, age, education level, ethnicity, length of profession. , main occupation, sources of knowledge and skills, as well as the location of the respondent's residence which has been mapped. Then the main variables consist of species of medicinal tree groups found, parts of plants used as medicinal commodities, locations for growing plant populations and medicinal plant processing processes.

The data that has been obtained in the form of qualitative were analyzed using descriptive analysis. Furthermore, the data is verified and interpreted through a literature study to be able to present the data and determine the validity of the data. Literature study is used to find out which plant species are used appropriately. 


\section{Results and Discussions}

\section{Companion Variable}

a. Characteristics of Research Area

\section{Table 1}

Climate Type of Each District

\begin{tabular}{|c|c|c|c|c|c|}
\hline No. & Zone & $\begin{array}{l}\text { Climatic } \\
\text { Type }\end{array}$ & $\begin{array}{l}\text { Wet } \\
\text { Month }\end{array}$ & $\begin{array}{l}\text { Dry } \\
\text { Month }\end{array}$ & Location District \\
\hline 1. & $\mathrm{C} 2$ & $\begin{array}{l}\text { Slightly } \\
\text { wet }\end{array}$ & $5-6$ & $3-4$ & $\begin{array}{l}\text { Montong Gading, Pringgasela, } \\
\text { Sembalun }\end{array}$ \\
\hline 2. & $\mathrm{C} 3$ & Moderate & $5-6$ & $4-6$ & Masbagik, Sikur, Aikmel, Lenek \\
\hline 3. & $\mathrm{C} 4$ & Moderate & $5-6$ & 7 & Terara, Sukamulia, Selong, Suralaga \\
\hline 4. & D3 & $\begin{array}{l}\text { Slightly } \\
\text { dry }\end{array}$ & $3-4$ & $4-6$ & $\begin{array}{l}\text { Keruak, Wanasaba, Sakra Barat, Suela, } \\
\text { Pringgabaya, Labuhan Haji, Sakra } \\
\text { Timur, Sakra }\end{array}$ \\
\hline 5. & D4 & Dry & $3-4$ & $7-9$ & Jerowaru, Sambelia \\
\hline
\end{tabular}

The division of the Oldeman climate type is based on the comparison of the number of dry months with the number of wet months in the year of observation. The dry month category is when the rainfall value is $100 \mathrm{~mm}$, the humid month category (moderate) is when the rainfall is 100 to $200 \mathrm{~mm}$ and the wet month category is when the total rainfall is $200 \mathrm{~mm} / \mathrm{month}$ (Fadholi \& Supriatin, 2012). In five years of observation, the climate type in East Lombok Regency ranges from zones C2 to D4 with a slightly wet to dry climate type, the climate type which is located from a slightly wet to dry type indicates that East Lombok Regency has quite a variety of climate types, thus affecting the growing location and cultivation of medicinal tree groups.

b. Characteristics of Respondents

Respondent characteristics greatly affect plant species and frequency use of plants as medicinal ingredients. Respondents who have social characteristics which are classified as low as at the level of education using group species more limited trees. This is because knowledge about plant management based solely on hereditary knowledge and skills.

\section{Table 2}

Characteristics of Research Respondents

\begin{tabular}{|c|c|c|c|}
\hline No. & Gender & Amount & $\begin{array}{c}\text { Percentage of Plant Species } \\
\text { Diversity Used }\end{array}$ \\
\hline 1. & Male & 8 & $28 \%$ \\
\hline \multirow[t]{2}{*}{2.} & Female & 17 & $72 \%$ \\
\hline & & 25 & $100 \%$ \\
\hline No. & Age & Amount & $\begin{array}{c}\text { Percentage of Plant Species } \\
\text { Diversity Used }\end{array}$ \\
\hline 1. & $30-40$ years & 2 & $21 \%$ \\
\hline 2. & $40-50$ years & 5 & $24 \%$ \\
\hline
\end{tabular}




\begin{tabular}{|c|c|c|c|}
\hline 3. & $>50$ years & 18 & $55 \%$ \\
\hline & & 25 & $100 \%$ \\
\hline No. & Level of education & Amount & $\begin{array}{c}\text { Percentage of Plant Species } \\
\text { Diversity Used }\end{array}$ \\
\hline 1. & No school & 12 & $33 \%$ \\
\hline 2. & $\begin{array}{l}\text { Not completed in } \\
\text { primary school }\end{array}$ & 2 & $23 \%$ \\
\hline 3. & Elementary School & 7 & $25 \%$ \\
\hline 4. & Junior high school & 1 & $5 \%$ \\
\hline 5. & bachelor & 3 & $14 \%$ \\
\hline & Total & 25 & $100 \%$ \\
\hline No. & $\begin{array}{l}\text { Old Profession } \\
\text { Batra }\end{array}$ & Amount & $\begin{array}{c}\text { Percentage of Plant Species } \\
\text { Diversity Used }\end{array}$ \\
\hline 1. & $1-10$ years & 3 & $20 \%$ \\
\hline 2. & $11-20$ years & 7 & $15 \%$ \\
\hline 3. & $21-30$ years & 2 & $14 \%$ \\
\hline 4. & $>30$ years & 13 & $51 \%$ \\
\hline & Total & 25 & $100 \%$ \\
\hline No. & $\begin{array}{l}\text { Source of } \\
\text { Knowledge }\end{array}$ & Amount & $\begin{array}{c}\text { Percentage of Plant Species } \\
\text { Diversity Used }\end{array}$ \\
\hline 1. & Family & 12 & $53 \%$ \\
\hline 2. & Experience & 5 & $12 \%$ \\
\hline 3. & Formal education & 1 & $24 \%$ \\
\hline 4. & $\begin{array}{l}\text { Non formal } \\
\text { education }\end{array}$ & 5 & $21 \%$ \\
\hline & Total & 40 & $100 \%$ \\
\hline
\end{tabular}

Most of the research respondents are female, this is because the perception of women who are considered more conscientious than men, so that medical knowledge and skills are passed on to woman. Then on the characteristics of age, most of the respondents are in the group more than 50 years old. Based on the research results of the Ministry of Health of the Republic of Indonesia Indonesia (2012), the age of traditional healers who are more than 50 years indicates lack of regeneration of traditional healers.

The education level of the respondents is mostly not in school, this indicates the low absorption of knowledge and innovation of the treatment activities carried out. Furthermore, the respondent's ethnicity comes from the Sasak Tribe which is the ethnic origin of the indigenous population in Indonesia Lombok island. The treatment carried out by the Sasak tribe mostly uses the bark and stems of medicinal plants as ingredients, in contrast to the Javanese which is more dominant using rhizomes. The traditional medicine profession has more than 30 years of experience. Based on the research results of (Dewi, D.A.R.H., Saskara, 2020), experience in a field profession affects the skill level of the actor, thereby increasing trust people who act as consumers of the products or services offered. Source knowledge of the processing of medicinal herbs carried out by Batra in 
part big comes from family. This is in line with the research results of the Ministry of Health year 2012 which states that, Batra generally only relies on knowledge and experience obtained empirically which is passed down from generation to generation, caused by Batra's education is low so that the absorption of information for medical activities is limited.

Tabel 3

Rekapitulasi Spesies Tanaman Kelompok Pohon yang Digunakan

\begin{tabular}{|c|c|c|c|c|c|}
\hline No & Local Name & Species Name & $\begin{array}{l}\text { Part of the } \\
\text { plant used }\end{array}$ & $\begin{array}{c}\text { Location of } \\
\text { plant } \\
\text { distribution }\end{array}$ & $\begin{array}{c}\text { percentage } \\
\text { of use in } \\
\text { medicinal } \\
\text { herbs }(\%)\end{array}$ \\
\hline 1. & Alpukad & Persea Americana & Leaf & Highland & 0,3 \\
\hline 2. & Aren & Arenga pinnata & Extrudate & Highland & 19,1 \\
\hline 3. & Asam jawa & Thamarindus indica & $\begin{array}{l}\text { Bark, flesh of } \\
\text { fruit }\end{array}$ & All plains & 6,4 \\
\hline 4. & Gempol & Nuclea oreantalis & Bark & Highland & 0,3 \\
\hline 5. & Beringin & Ficus benjamina & Bark & All plains & 2,0 \\
\hline 6. & Bidara & Ziziphus mauritiana & Leaf, fruit & Lowland & 0,3 \\
\hline 7. & Cengkeh & Syzygium aromaticum & Flower & Highland & 4,5 \\
\hline 8. & Delima & Punica granatum & Bark, rind & Lowland & 1,0 \\
\hline 9. & Dewandaru & Eugenia uniflora & Bark & Highland & 0,3 \\
\hline 10. & Jamblang & Syzygium cumini & Bark, stem & Lowland & 4,5 \\
\hline 11. & Kayu jawa & Lannea coromandelica & Bark & All plains & 2,7 \\
\hline 12. & Kayu manis & Cinnamon vereum & Bark & Highland & 5,5 \\
\hline 13. & Kayu putih & Melaleuca cajuputi & Leaf & Lowland & 1,0 \\
\hline 14. & Kelapa & Cocos nucifera & Biji & Lowland & 4,5 \\
\hline 15. & $\begin{array}{l}\text { Bunga } \\
\text { lawang }\end{array}$ & Illicium verum & Fruit & Highland & 1,2 \\
\hline 16. & Kemenyan & Styrax benzoin & Extrudate & Highland & 1,2 \\
\hline 17. & Kemiri & Aleurities moluccanus & Seed & Highland & 2,4 \\
\hline 18. & Kersen & Muntingia calabura & Bark & Lowland & 0,3 \\
\hline 19. & Ketapang & Terminalia catappa & Leaf & Lowland & 0,3 \\
\hline 20. & Kluwih & Artocarpus camansi & Leaf & All plains & 2,7 \\
\hline 21. & Lamtoro & Leucaena leucocephala & Leaf & Lowland & 1,5 \\
\hline 22. & Mahoni & Swietenia mahagoni & Seed & All plains & 0,5 \\
\hline 23. & Manggis & Garcia mangostana & Rind & Lowland & 2,4 \\
\hline 24. & Masuyi & Cryptocarya massoia & Bark & Highland & 1,3 \\
\hline 25. & Mimba & Azadirachta indica & Bark, leaf & Lowland & 1,0 \\
\hline 26. & Nangka & $\begin{array}{l}\text { Artocarpus } \\
\text { heterophyllus }\end{array}$ & Leaf & All plains & 1,5 \\
\hline 27. & Pala & Myristica fragrans & Seed & Highland & 9,1 \\
\hline 28. & Pasak bumi & Eurycoma longifolia & Root & Highland & \\
\hline 29. & Pinang & Areca catechu & Seed & Highland & 13,6 \\
\hline 30. & Pulai & Alstonia scholaris & Bark & Lowland & 0,8 \\
\hline 31. & Secang & Caesalpinia sappan & Bark, stem & Highland & 1,0 \\
\hline
\end{tabular}




\begin{tabular}{llllll}
\hline No & Local Name & Species Name & Part of the & $\begin{array}{c}\text { Location of } \\
\text { plant used } \\
\text { plant } \\
\text { distribution }\end{array}$ & $\begin{array}{c}\text { percentage } \\
\text { of use in } \\
\text { medicinal } \\
\text { herbs (\%) }\end{array}$ \\
\hline 32. & Sengon & Albizia chinensis & Bark & All plains & 0,9 \\
\hline 33. & Seprantu & Sindora sumatrana & Fruit & Highland & 1,5 \\
\hline 34. & Sirsak & Annona muricata & Leaf & All plains & 1,0 \\
\hline 35. & Sukun & Artocarpus altilis & Leaf & All plains & 1,5 \\
\hline 36. & Trenggulun & Protium javanicum & Bark & Highland & 1,0 \\
\hline
\end{tabular}

The results of the exploration of the plants used, of the 36 plant species only nine species of plants that have been cultivated, namely Persea Americana, Arenga pinnata, Thamarindus indica, Syzygium aromaticum, Punica granatum, Aleurities moluccanus, Garcia mangostana, Myristica fragrans and Areca catechu. As for other plants are obtained from buying and selling activities, taking directly in nature or imported from outside the island of Lombok. In addition, from the 36 plant species there are 20 plant species that have economic value and have been used by the wider community as plant commodities with economic value, including Persea Americana, Syzygium aromaticum, Punica granatum, Cinnamon vereum, Melaleuca cajuputi, Cocos nucifera, Illicium verum, Styrax benzoin, Aleurities moluccanus, Swietenia mahagoni, Garcia mangostana, Cryptocarya massoia, Artocarpus heterophyllus, Myristica fragrans, Eurycoma longifolia, Caesalpinia sappan, Sindora sumatrana, Annona muricata, Artocarpus altilis and Syzygium cumini. While other plant species, namely Nuclea oreantalis, Ficus benjamina, Ziziphus mauritiana, Eugenia uniflora, Muntingia calabura, Terminalia catappa, Artocarpus camansi, Leucaena leucocephala, Azadirachta indica, Alstonia scholaris and Albizia chinensis, is only used as raw material for medicine by Batra and is not for sale buy it. This is caused by several things, such as the availability of these plants is sufficien many and easy to find.

Aren (Arenga pinnata) is the most widely used plant species to make medicinal herbs reach 21 potions with a percentage of $19.1 \%$ of the total species of medicinal tree groups found. Sugar palm extrudate is used as a sweetener so that it can offer a bitter taste from other medicinal ingredients. In addition, sugar palm is believed to be an energy enhancer in the medicinal ingredients that are made. This is in line with the results of Lempang's research (2012), that sugar palm extrudates contain carbohydrate nutrients reach $11.28 \%$ so that it can be a source of energy.

c. Plant Parts Used for Medicine

Table 6

Recapitulation of Plant Parts Used for Traditional Medicine

\begin{tabular}{llc}
\hline No. & Plant Parts & Amount \\
\hline 1. & Bark & 16 \\
2. & Leaf & 12 \\
\hline
\end{tabular}




\begin{tabular}{llc}
\hline No. & Plant Parts & Amount \\
\hline 3. & Stem & 12 \\
4. & Seed & 5 \\
5. & Fruit & 3 \\
6. & Rind & 2 \\
7. & Extrudate & 2 \\
8. & Flower & 2 \\
9. & Root & 1 \\
\hline
\end{tabular}

The bark of tree plants is the most widely used, because it is believed by traditional healers that it is the part of the plant that contains the most nutritious compounds, so it is widely used as a medicinal ingredient. The bark of the tree group has a complex bark structure, so that its structure can be distinguished from the trunk. This makes it easier to take the bark as a medicinal ingredient from plants. Anatomically, the bark of the stem is called phloem, which is a network for the distribution of photosynthetic products from all parts of the plant (Sari, 2016) argues that phloem is a transport network that functions to transport photosynthetic products throughout the plant body, because it functions to transport photosynthetic products in the form of primary and secondary metabolites, so the bark is assumed to contain many active compounds that can be used as raw materials for traditional medicines.

\section{d. Plants Growing Locations Used for Medicine}

Table 7 plant growing population found

\begin{tabular}{llc}
\hline No. & Plain elevation & Amount \\
\hline 1. & Highland $(\geq 500$ masl $)$ & 19 \\
3. & All plains & 12 \\
2. & Lowland $(\leq 500$ masl $)$ & 9 \\
\hline
\end{tabular}

The division of highland and lowland zones was carried out based on research conducted by (Ikawati, Sunaryo, \& Widiastuti, 2015) which divides the altitude into two, namely highlands and lowlands, where lowlands are the earth's surface from an altitude of 0-500 masl, while highlands are the earth's surface with an altitude above 500 masl. Most of the respondents came from the lowlands, but based on the location of the plants it was found that most of them came from the highlands, indicating that many types of medicinal tree group plants were not cultivated by Batra, but were obtained from other products such as buying and selling. Therefore, it is very necessary to carry out the cultivation of medicinal plants by considering the location of plant cultivation in accordance with the characteristics of its growth.

Cultivation activities of medicinal tree group plants really need to consider the climate type of the cultivation location, so that plant growth and yields are optimal. In addition, plant cultivation in accordance with the growth criteria causes the content of secondary metabolites that are used as medicinal ingredients in plants 
Etnobotany Medicinal Plants Tree Group In Traditional Medicine At East Lombok Regency

to be more optimal (Abdullah et al., 2010). Therefore, mapping the location of tree cultivation according to the optimal climate type in each sub-district in East Lombok Regency. The recapitulation of plant cultivation locations according to the optimal climate criteria in East Lombok Regency is presented in the following table,

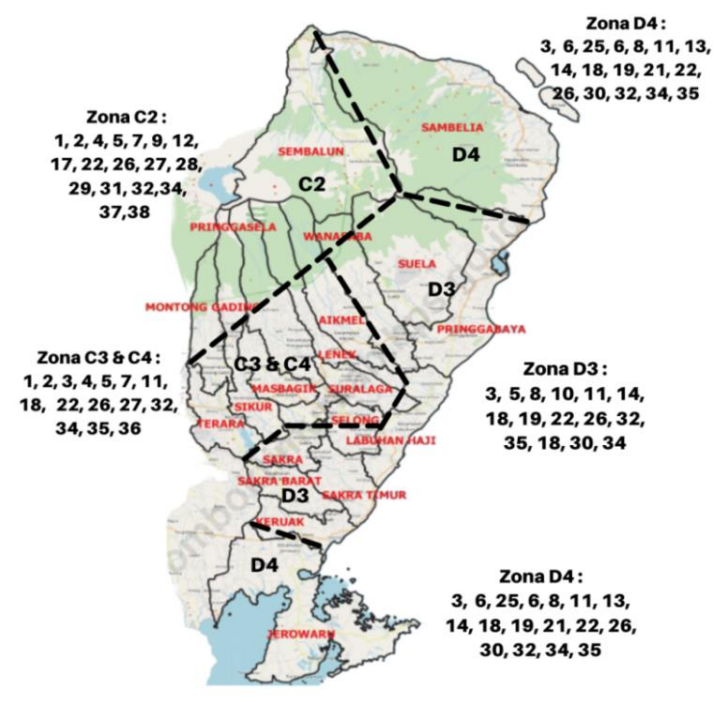

Symbol description :

\begin{tabular}{|c|c|c|c|c|}
\hline 1 & Persea americana & 20. & : & Artocarpus camansi \\
\hline 2 & Arenga pinnata & 21. & $:$ & Leucaena leucocephala \\
\hline 3 & Tamarindus indica & 22. & : & Swietenia mahagoni \\
\hline 4 & Nuclea oreantalis & 23. & $:$ & Garcia mangostana \\
\hline 5 & Ficus benjamina & 24. & $:$ & Cryptocarya massoia \\
\hline 6 & : Ziziphus mauritiana & 25. & $:$ & Azadirachta indica \\
\hline 7 & : Suziginium aromaticum & 26. & $:$ & Artorocarpus heterophyllus \\
\hline 8 & : Punica granatum & 27. & $:$ & Myristica fragrans \\
\hline 9 & : Eugenia uniflora & 28. & $:$ & Eurycoma longifolia \\
\hline 10 & : Syzygium cumini & 29. & $:$ & Areca catechu \\
\hline 11. & : Lannea coromandelica & 30. & : & Alstonia scholaris \\
\hline 12. & : $\quad$ Cereum vereum & 31. & $:$ & Caesalpinia sappan \\
\hline 13. & : Maleleuca cajuputi & 32. & $:$ & Albizia chinensis \\
\hline 14. & : Cocos nucifera & 33. & $:$ & Sindora sumatrana \\
\hline 15. & : Irrium verum & 34. & $:$ & Annona muricata \\
\hline 16. & $: \quad$ Styrax benzoin & 35. & $:$ & Artocarpus altilis \\
\hline 17. & : Aleurites moluccanus & 36. & $:$ & Protium javanicum \\
\hline 18. & : Muntingia calabura & & & \\
\hline 19. & : Terminalia catappa & & & \\
\hline
\end{tabular}


e. Medicinal Herbs made by Batra

\section{Table 8}

Medicinal herb form

\begin{tabular}{llc}
\hline No. & Medicinal herb form & Amount \\
\hline 1. & Liquid herb & 20 \\
2. & Solid ointment & 8 \\
3. & Oil & 5 \\
4. & Powder & 4 \\
5. & Bubusan & 2 \\
6. & Mamak & 2 \\
\hline
\end{tabular}

Most forms of medicinal herbs are made in the form of liquid herbs that are used as internal medicine. According to research results, liquid herbal medicine is made because it feels effective faster and is easier in the manufacturing process. However, the lack of liquid herbal medicine is that it is more easily damaged due to bacterial contamination, so liquid herbal medicine is a type of herbal medicine for short-term consumption. The medicinal ingredients made by Batra are usually claimed to have properties that are quite varied in treating a symptom of a disease. This is due to Batra's past experience which successfully treated a disease complaint with a prescription that had been made by Batra himself.

Bubusan is a form of concoction mixed with whiting and used by mixing it with water and then applied to the affected body part, or used in external medicine. The mamak is a form of concoction that is chewed by Batra until it is slightly smooth, then smeared on the sick patient's body.

Table 9

Recapitulation of herb efficacy based on disease symptoms

\begin{tabular}{llcclc}
\hline No. & Disease Symptoms & Jumlah & No. & Disease Symptoms & Jumlah \\
\hline 1. & Fever & 9 & 15. & Fracture & 4 \\
2. & Stomach pain & 9 & 16. & Kidney stones & 4 \\
3. & Sprain & 9 & 17. & Diabetes & 3 \\
4. & Energy boost & 9 & 18. & Menstural pain & 3 \\
5. & Digestion illness & 8 & 19. & Increase appetite & 3 \\
6. & External wound & 8 & 20. & High blood pressure & 2 \\
7. & postpartum & 6 & 21. & Joint pain & 2 \\
8. & Lowering blood presure & 6 & 22. & Magh & 2 \\
9. & Body aches & 6 & 23. & Smooth digestion & 2 \\
10. & Bruises & 6 & 24. & Urinary tract infection & 1 \\
11. & Wrong vein & 5 & 25. & Cyst & 1 \\
12. & Cold & 5 & 26. & Throws up & 1 \\
13. & Gout & 5 & 27. & Vaginal discharge & 1 \\
14. & Cholesterol & 5 & 28. & Imflamatin & 1 \\
\hline
\end{tabular}

There are 28 types of disease symptoms that are recognized to be treatable by medicinal herbs produced by Batra based on Batra's empirical experience in 
doing treatment. Of the 28 types of disease, there are 10 types of disease symptoms which are mostly produced by the type of ingredients by Batra. namely fever, stomach pain, sprains, energy boosters, digestive pain, external wound, postpartum, lowering blood pressure, body aches and bruising. The ingredients for this type of disease are, of course, produced by Batra because people often complain about getting treatment at the Batra.

\section{Conclusions}

Based on the research that has been done, it can be concluded that, Batra in East Lombok Regency found 36 species of medicinal tree groups that have been used empirically to treat a disease symptom, of the 36 species there are 10 species of plants that have been cultivated and 21 species of plants with economic value.

There are 10 tree species that are most widely used in medicinal activities by Batra based on their use in medicinal herbs so that they have the potential to be developed into medicinal plant commodities including Arenga pinnata extrudates, Areca catechu seeds, Myristica fragrans seeds, Thamarindus indica fruit flesh, Cinnamon vereum bark, Syzygium aromaticum flowers, Syzygium cumini bark, Cocos nucifera endosperm, Artocarpus camansi leaves and Lannea coromandelica bark.

There are 28 types of disease symptoms made by Batra and there are 10 types of disease symptoms that Batra produces the most types of ingredients, namely fever, stomach pain, sprains, energy boosters, digestive pain, external wounds, postpartum, lowering blood pressure, body aches and bruising. 


\section{BIBLIOGRAFI}

Abdullah, Muhammad, Mustikaningtyas, Dewi, \& Widiatningrum, Talitha. (2010). Inventarisasi Jenis-Jenis Tumbuhan Berkhasiat Obat di Hutan Hujan Dataran Rendah Desa Nyamplung Pulau Karimunjawa. Biosaintifika: Journal of Biology \& Biology Education, 2(2).Google Scholar

Ariandi, Ariandi, \& Khaerati, Khaerati. (2016). Identifikasi indeks keanekaragaman tanaman obat-obatan di kawasan hutan Kelurahan Battang dan Battang Barat. Prosiding, 2(1). Google Scholar

Dahlia, Intan Shopia. (2016). Kajian Etnobotani Tumbuhan Obat Oleh Masyarakat Desa Jayamekar Kabupaten Bandung Barat. Fkip Unpas. Google Scholar

Dewi, D.A.R.H., Saskara, I. A. .. (2020). Pengaruh Keterampilan Kerja, Jam Kerja, Lama Usaha terhadap Pendapatan Pengerajin Industri Kerajinan Mozaik. Ekonomi Pembangunan Universitas Udayana, 9, 1473-1501.

Dewi, Ni Ketut Lestari, Jamhari, Muhammad, \& Isnainar, Isnainar. (2017). Kajian Pemanfaatan Tanaman Sebagai Obat Tradisional Di Desa Tolai Kecamatan Torue Kabupatenparigimoutong. E-Jip Biol, 5(2). Google Scholar

Fadholi, Akhmad, \& Supriatin, Dina. (2012). Sistem pola tanam di wilayah Priangan berdasakan klasifikasi iklim Oldeman. Jurnal Geografi Gea, 12(2). Google Scholar

Gazali, M., Zamani, N., Nurjanah, N. (2011). Perilaku Pencarian Pengobatan terhadap Kejadian Penyakit Malaria pada Suku Mandar di Desa Lara Kecamatan Karossa Kabupaten Mamuju Provinsi Sulawesi Barat. Jurnal Kesehatan Masyarakat, 12, 156-165.

Herdiani, Elvina. (2012). Potensi tanaman obat indonesia. BBPP Lembang. Kementrian Pertanian, Badan Penyuluh Dan Pengembangan SDM Pertania. Retrieved from Http://Www. Bbpp-Lembang. Info/Index. Php/Arsip/Artikel/Artikel-Pertanian/585Potensi-Tanaman-Obat-Indonesia. Google Scholar

Ikawati, Bina, Sunaryo, Sunaryo, \& Widiastuti, Dyah. (2015). Peta status kerentanan Aedes aegypti (Linn.) terhadap insektisida cypermethrin dan malathion di Jawa Tengah. ASPIRATOR-Journal of Vector-Borne Disease Studies, 7(1), 23-28. Google Scholar

Lesmana, Hendy, Alfianur, Alfianur, Utami, Putri Ayu, Retnowati, Yuni, \& Darni, Darni. (2018). Pengobatan tradisional pada masyarakat tidung kota Tarakan: study kualitatif kearifan lokal bidang kesehatan. Medisains, 16(1), 31-41. Google Scholar

Nasution, Dito Aditia Darma, Erlina, Erlina, \& Muda, Iskandar. (2020). Dampak Pandemi COVID-19 terhadap Perekonomian Indonesia. Jurnal Benefita, 5(2), 212. Google Scholar 
Nugroho, Ardiyanto W. (2017). Konservasi Keanekaragaman Hayati Melalui Tanaman Obat Dalam Hutan Di Indonesia Dengan Teknologi Farmasi: Potensi Dan Tantangan. Jurnal Sains Dan Kesehatan, 1(7), 377-383. Google Scholar

Riau, Penyengat Village Sungai Apit Siak. (2019). Etnobotani Dan Potensi Tumbuhan Obat Masyarakat Etnik Anak Rawa Kampung Penyengat Sungai Apit Siak Riau. Google Scholar

Riswan, Soedarsono, \& Andayaningsih, Dwi. (2008). Keanekaragaman tumbuhan obat yang digunakan dalam pengobatan tradisional masyarakat sasak lombok barat. Jurnal Farmasi Indonesia, 4(2), 96-103. Google Scholar

Sari, Ayu Nirmala. (2016). Berbagai tanaman rempah sebagai sumber antioksidan alami. Elkawnie: Journal of Islamic Science and Technology, 2(2), 203-212. Google Scholar

Suryanto, Rusli, \& Setiawan, Djoni. (2013). Struktur Data Datawarehouse Tanaman Obat Indonesia Dan Hasil Penelitian Obat Tradisional. SESINDO 2013, 2013. Google Scholar

\section{Copyright holder:}

Lalu Gin Gin Budiarsa, Nurrachman, Sumarjan (2021)

\section{First publication right:}

Syntax Idea

\section{This article is licensed under:}

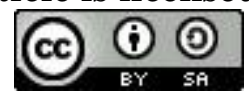

